\title{
RETHINKING VISUAL REPRESENTATION; NOTES ON THE FOLKLORIST AND PhOTOGRAPHER NiLS KEYLAND
}

\author{
Jan Garnert
}

The camera is a paradoxical instrument. It records, generally speaking, truthfully what is in focus, but it is the photographer who chooses what should be in focus. Therefore, in a sense, any photograph is nothing but a construction by the photographer. This paradox is of some importance to folklorists, ethnologists, and museum curators, I believe, as photographs often play an important part in our fieldwork, as source material in our archives, and as interpretive elements in our exhibitions. Photographs are taken, kept and archived because they are considered to represent valuable meanings for a folkloristic and ethnological understanding of culture and cultural history. At least we usually treat them in our research and in our writings as if they represent important fields of research interests.

But, as with every source material, be it interviews, narratives, literary sources or whatever, photographs need to be carefully examined and evaluated. What do they represent? In this article I will discuss the question of representation, using as an example the photographs taken in the early 20th century by Nils Keyland, folklorist and curator at the Nordiska Museet and Skansen in Stockholm.'

Keyland's photographic documentation and his use of the camera is indeed an interesting example, greatly because his photographs are today frequently utilized in Sweden as a most important cultural historical source material. They are utili- zed so frequently that they can to a certain extent be said to represent the photographic imagery of turn of the century Swedish folklife. I shall also analyze the methodological thinking that served as a basis for Nils Keyland's photographic work. 
170 But first I will give some biographical data about Keyland, as they appear in the writings of some of Keyland's colleagues and in the yearbooks of the Nordiska Museet.

\section{HUMBLE CHILDHOOD}

Nils Keyland was born in 1867, a year of bad harvests in Sweden, followed by hunger that created an increase in the number of Swedes abandoning their native country for a hopefully more prosperous future in the United States. His mother came from a family of Finnish origin, she was a descendant of the immigrants from Finland who once had broken new land in the woodlands in Värmland, a province in Mid-western Sweden which was scarcely populated through the centuries.

Nils Keyland's parents had a small farm where the soil was hard to cultivate. The district can be described as barren and the family household as poor - the childhood of Nils Keyland was humble. The likely fate of Nils Keyland would have been to cultivate the land or maybe to leave his parents to work in the prosperous timber industry or the growing pulp industry. $\mathrm{He}$ could also, as thousands of others did, have chosen to emigrate to the United States.

$\mathrm{He}$ did neither. After the compulsory elementary school he somehow managed to become a student at a secondary grammar school, a few years later, in 1890, he left the university as a Bachelor of Arts. He wanted to become a teacher in languages and in order to improve his knowledge of English he went abroad, to the United States, where he worked for a time as a railway worker. Sometimes he studied for as long as his finances allowed, then he took a new job, and after that took up his studies again. For a period he even was a teacher in Latin and French at Hope Academy in Moorhead, Minnesota.

But he overworked himself, collapsed, and returned to Sweden to recover. And that is where the direction of his life was changed by no less than Artur Hazelius, who in Stockholm was building the Nordiska Museet and Skansen, the world's first open air museum. Keyland was asked to help Hazelius in documenting and collecting artifacts from the old Finnish culture in Värmland.

The clergyman C. V. Bromander, who introduced Keyland to Hazelius, described Keyland in a letter by pointing out that:

his parents are descendants of the Finns and as a farmer's son he is indeed familiar with the customs of that population. His mother still speaks some Finnish.

According to the clergyman it would be a good idea to choose Keyland as a «collector" for the museum, because of his

many gifts and huge knowledge; a genius for languages, mathematician, drawer, poet, musical. In Värmland no one knows the ways of the Finnish population better than he does. But he is poor. Without some financial support little will be achieved.

Keyland himself commented on the work he was about to commence in a letter to Hazelius:

If I set out now it will be at the eleventh hour. The Finnish folk ways are about to disappear, the race is Germanized, the language is dying, the traditional 
Finnish ploughs are lying upside down, the birchbark rucksacks are slumbering in the attics, together with the worn out birch-bark shoes. The tar is imported, the old saunas are used up as material for making charcoal. Traditional dishes like hilo, mutti, resk, and bänkvälling are nowadays only eaten for fun. Folk beliefs are no more taken for Gospel truth.

Commenting on his fee, Keyland told Hazelius that he was "very poor».

Within a year Keyland was sending loads of artifacts to Stockholm, he made drawings of buildings, wrote down folk tunes, sleight-of-hand tricks, children's games, and other traditions. Years later in 1919 he published his major work, a book on traditional Swedish foodways, entitled Svensk allmogekost (Keyland 1989). The book remains the most thorough description of Swedish traditional foodways.

\section{NILS KEYLAND AS PHOTOGRAPHER}

Svensk allmogekost places Nils Keyland among the important Swedish folklorists, ethnologists and cultural historians of the early 20th century, but it is his use of the camera that makes him unique among the turn-of-the-century folklorists and museum curators. His collection of photographs is kept in the archive of the Nordiska Museet. Probably his oldest photograph dates back to 1901 , but most of his photographs were taken between 1904 and 1922.

Keyland also photographed artifacts, as his colleagues did, but more important, he used his camera for taking pictures of that which other cultural historians usually did not understand the value of, or at least showed very little or no interest at all before the late $1920 \mathrm{~s}$. In the early 20th century cameras were sparsely used for cultural historical documentation. If they were carried along at all in fieldwork, the pictures that were taken usually show exteriors of houses and artifacts like tools, furniture, and household utensils. The lowest common denominator in these pictures is usually that all persons are absent. ${ }^{2}$

This is not, however, the case in Nils Keyland's photographs. In his pictures the individuals who make use of the furniture and live in the houses are, on the contrary, given a central placing, which means that Nils Keyland photographed men and women in their surroundings; he showed them in a culturally meaningful setting. From these photographs one gets the impression that Nils Keyland was working from a fundamental principle according to which the houses and artifacts that surround us are more comprehensible if photographed in connection with the dwellers of the houses and the users of the furniture.

In this reasoning a main task for the folklorist and the museum curator is to show the artifacts and houses in use. For Nils Keyland an artifact which he decided to document by photographing it, was therefore incomplete if the person who used the artifact was not also photographed. Accordingly, no tool is fully documented unless the scholar documents how it is used.

Keyland also realized that in order to document working-life with the camera, more than one picture had to be taken. Thus he took sequences of pictures, showing the work as well as the use of tools for hay-making, threshing, tar-making, and basketry. A good example of this tech- 

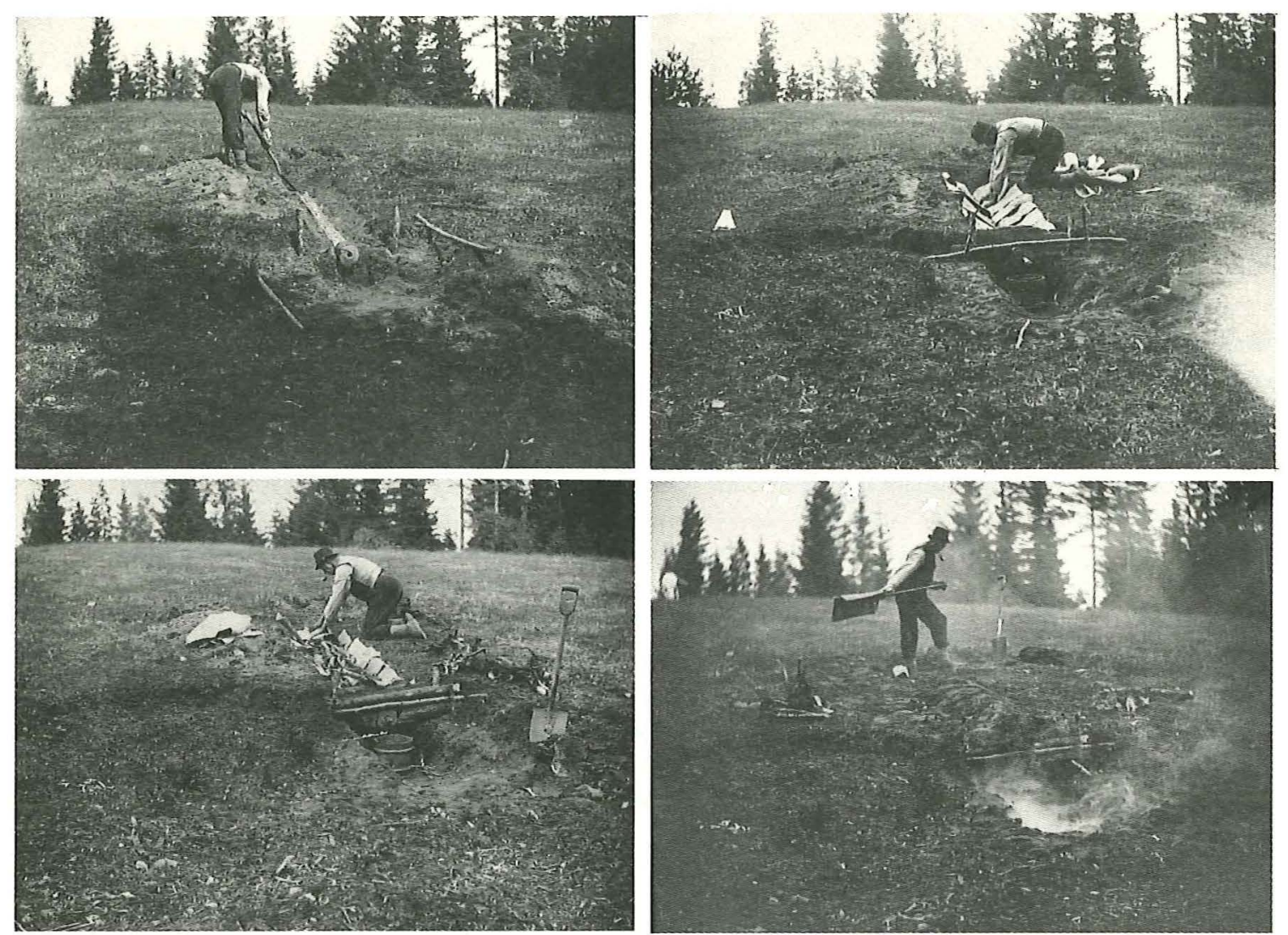

Photos nos. 1-4. Tar-making in Gunnarskog parish, 1922.

nique are his pictures showing small scale tar-making in a tar ditch (photos nos. 1-4).

Another photograph (photo no. 5), showing the work as well as the use of tools, depicts a woman working with a chopping-knife, mincing the meat needed for sausages and other traditional dishes. It is important to note that in this photograph Keyland does not primarily show the tool, but the work. He has documented how the chopping-knife was to be held properly as well as documenting the trough in which the meat was minced.

A third example is the picture with two women shearing sheep (photo no. 6). The shearer, as shown by the woman to the right in this picture, usually began from the sheep's throat, while standing astride the sheep. Then she would sit down, with the sheep on her knee, using her left hand for holding away the wool, in order to see clearly the points of the shears. This is shown by the woman sitting. The photograph was taken in 1911 .

Nils Keyland used the photographs to illustrate his articles and books. From the titles he gave them we can infer that he considered the pictures to be a prominent part of his articles. It is significant that the word "picture» is often included in the titles. The article "Some traditional ways of tarmaking» was published in 1925 with the subtitle "Pictures and notes from Värmland". Other articles by Keyland, like the ones on harvesting, leaf-harvesting, and slaughtering of reindeer, also carry the subtitles "Pictures and notes».

It is clear that Nils Keyland's published photographs herald something basically new in comparison with the contemporary scholarly use of photographs. His pictures never work as «illustrations» but are 


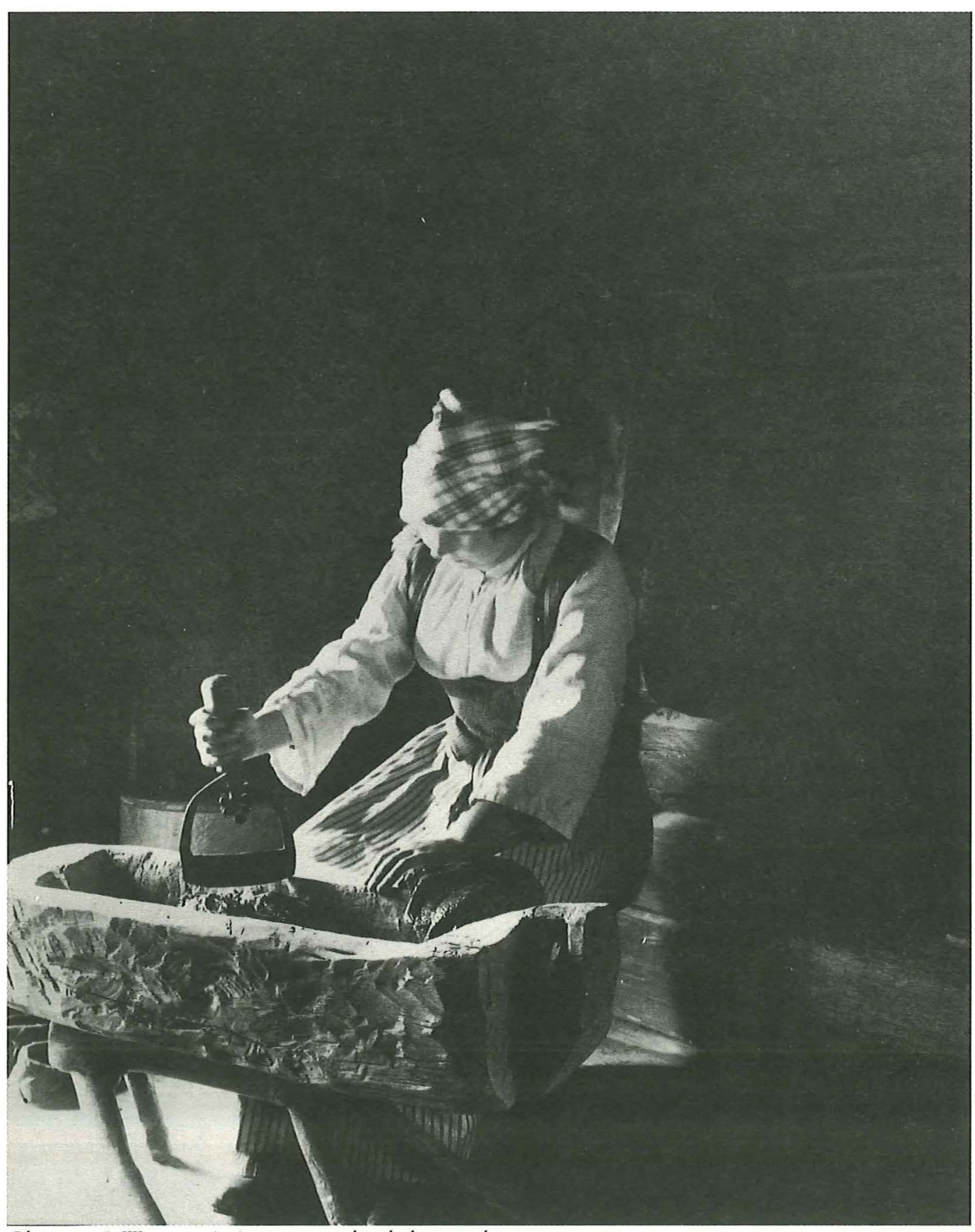


JAN GARNERT

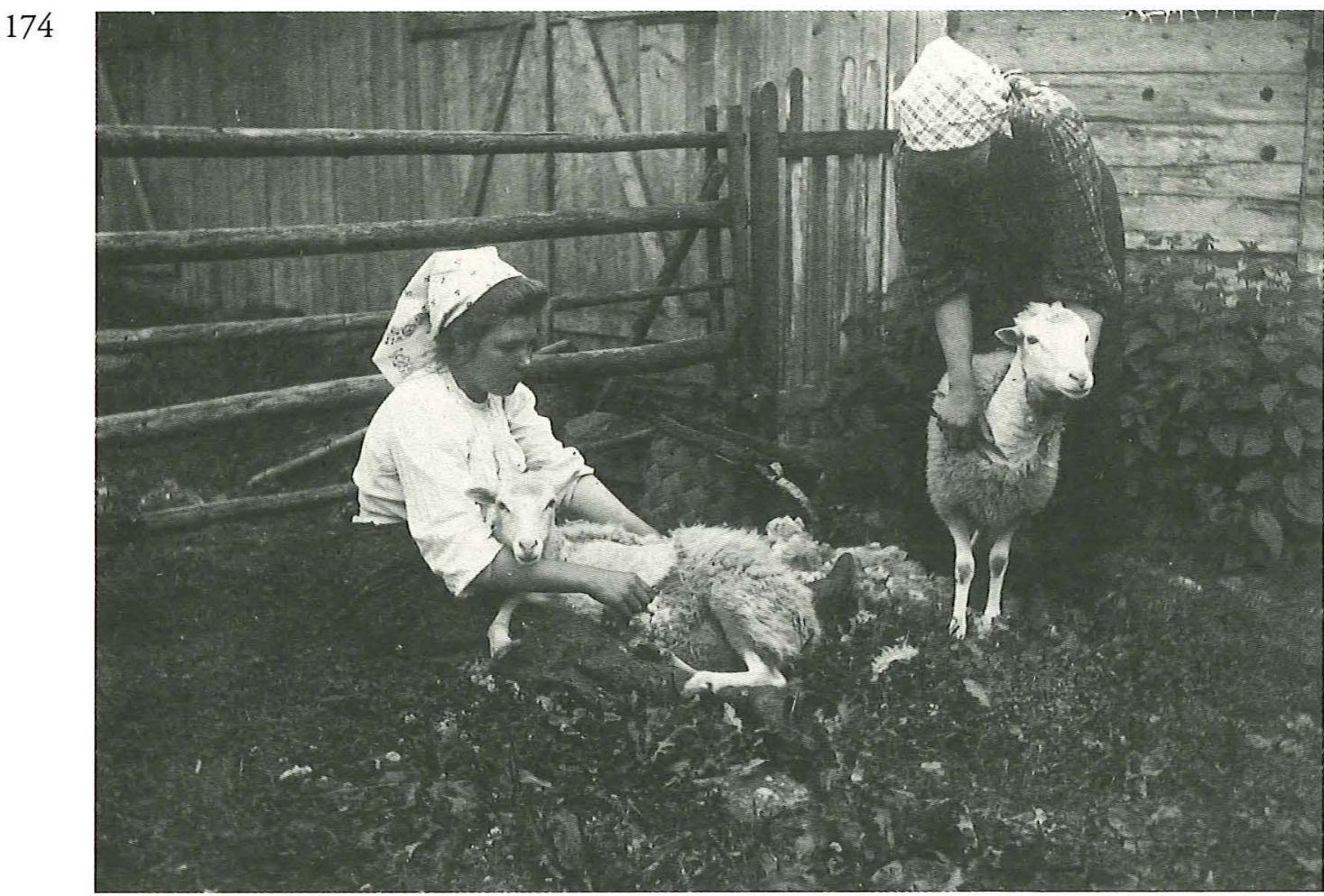

Photo no. 6. Two women shearing sheep in Mangskog, 1911.

an integral part of the analysis and the description. Nils Keyland was the first Swedish professional cultural historian who not only took photographs of cultural historical value, but systematically used his camera to produce cultural historical documents.

There were many photographers who in the early 20th century took pictures that we today regard as cultural historical documents. But, I think it is important to bear in mind that they all worked for goals other than those of the professional folklorist, ethnologist and cultural historian. Unfortunately, Nils Keyland has left no written evidence of the theoretical thinking which must have worked as a basis for his unusual way of photographing. Instead we must rely on our own evaluation of this photography.

I have already concluded that Nils Keyland must have been convinced that houses, tools, and other artifacts need to be documented in a context. But maybe this is the wrong way of evaluating his photographs? Maybe Nils Keyland did not primarily want to document material culture, but to portray the people of his province in their cultural historical setting? Perhaps this was the case, but I do not consider it likely. After all, that would be too modern an approach to folklife studies 


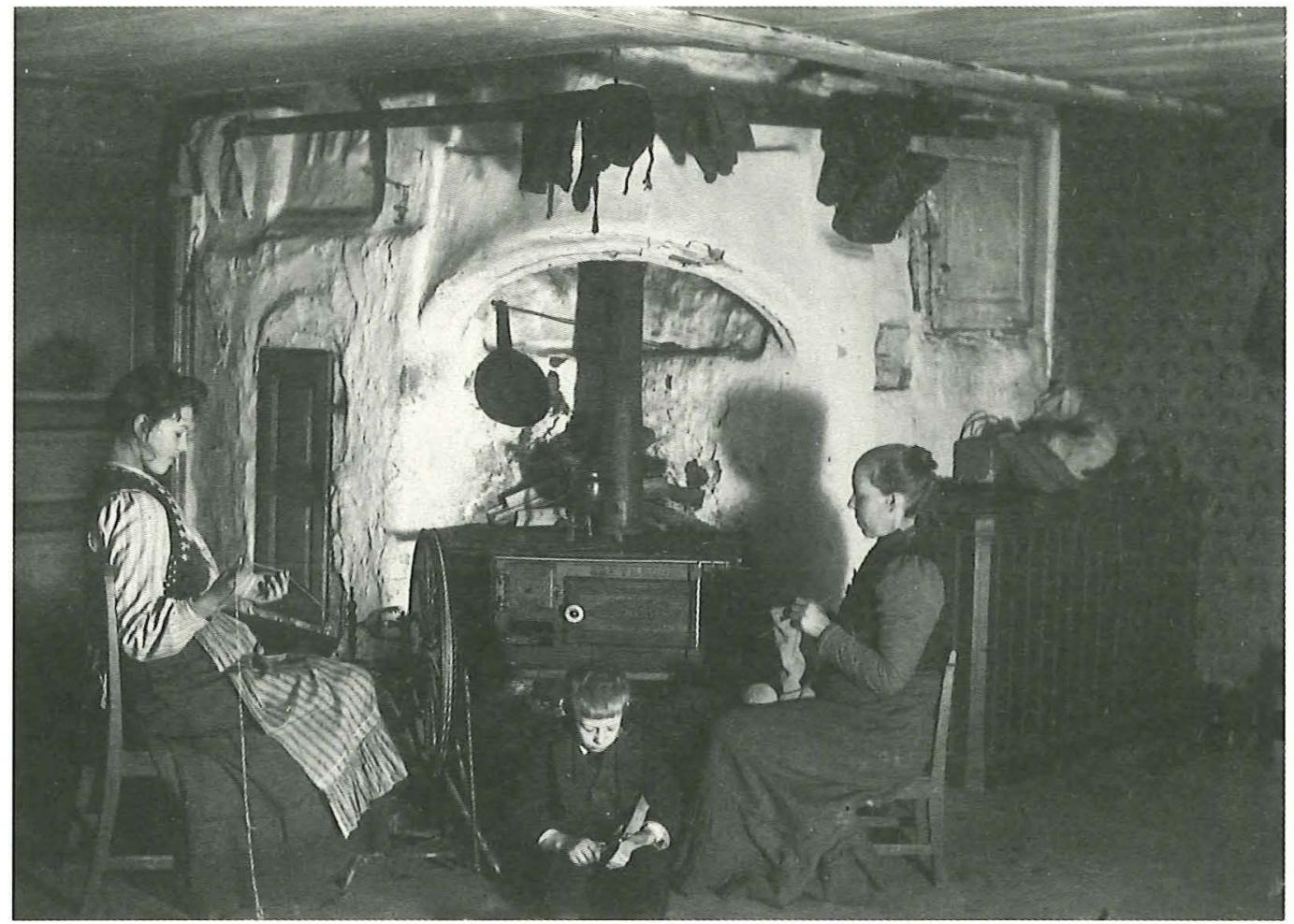

Photo no. 7. Family members gathered in front of an iron range, Gunnarskog, 1910.

as Keyland lived in an age when typological and evolutionary dogmas were the guiding-stars for cultural historians.

One example of his interest in photographing people and artifacts together is a picture showing two women and a boy in front of an iron range, a photograph taken in Gunnarskog parish in 1910 (photo no. 7). Ester is spinning, Albert is cutting sticks for the rushlights, their mother Maja Gylén is knitting. Keyland photographs the stove all right, it is definitely given a central position, but he has primarily produced a document showing typical female evening occupations and a typical child's task, necessary before the age of kerosine lamps and electric lighting. The picture also stresses the social function of the stove. It was only in front of the stove that it was warm enough for the family to sit in wintertime.

Nils Keyland's role as a pioneer becomes evident if we compare his picture of the iron range with pictures of stoves in Sigurd Erixon's voluminous work on furniture and home furnishing in Sweden, Möbler och heminredning $i$ svenska bygder, published in 1925-1926. Erixon, by then a curator at the Nordiska Museet, and from 1934-1955 the holder of the joint professorship at the Institute for Folklife Studies at the Nordiska Museet and 
JAN GARNERT

176

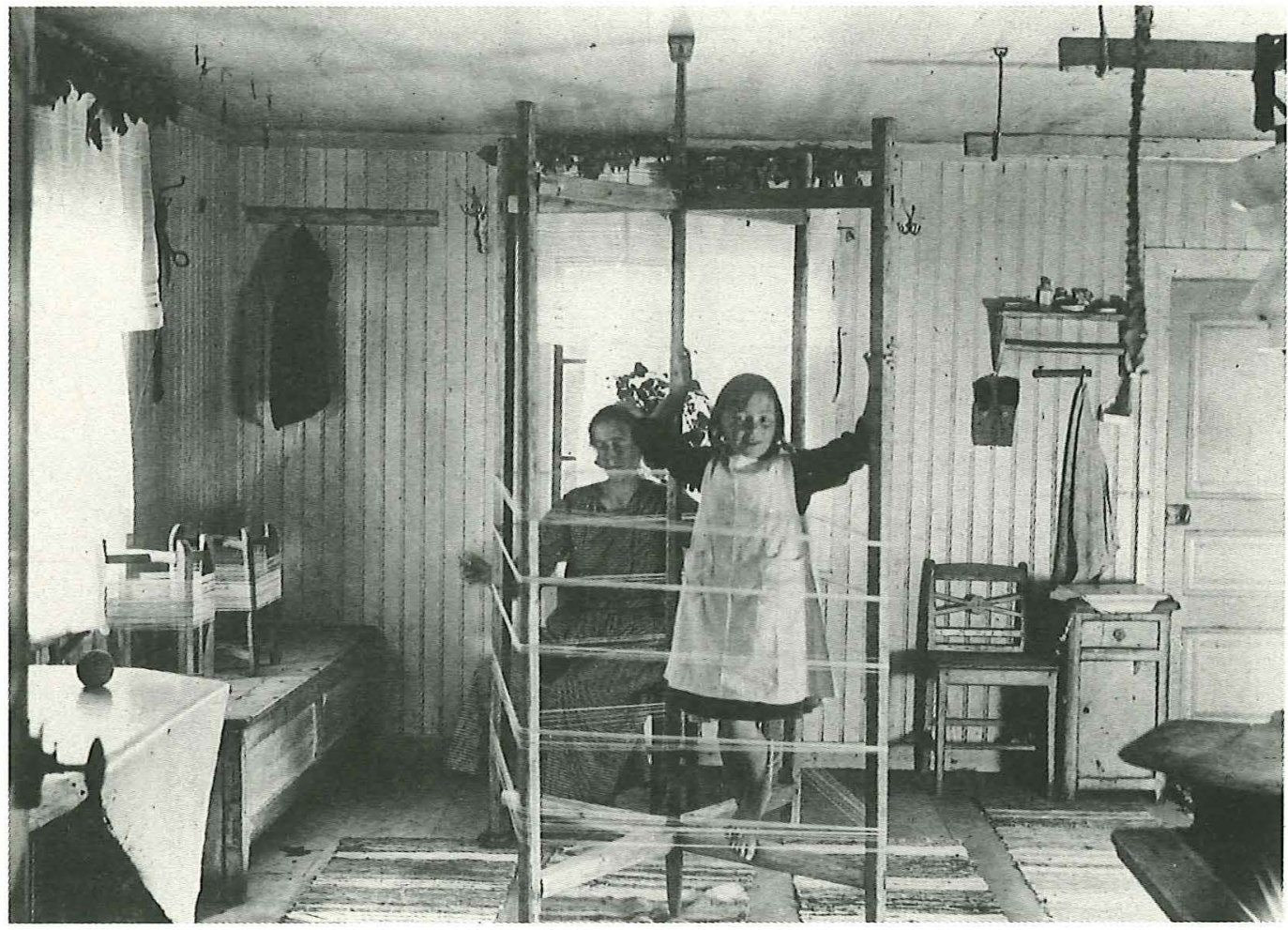

Photo no. 8. Warping woman, Mangskog, 1919.

Stockholm University, was for decades the leading ethnologist in Sweden, primarily devoted to studies in material culture and studies of social organization.

In his material culture studies, Erixon was most interested in, for example, the shape of the hood of stoves. This kind of information was needed as a trait for mapping in the Atlas över svensk folkkultur, (Atlas of Swedish Folk Culture). This more or less art historical interest is a general feature in Erixon's richly illustrated book, in which hardly any individuals are visible in the photographs. They were, it seems, told to keep out of the pictures.

Among Nils Keyland's photographs, on the contrary, it is hard to find pictures of stoves or iron ranges without human presence. When other scholars documented the shape of stoves, Nils Keyland documented their functions. His pictures do not depict material vernacular culture but rather "folk" in a material context. In a few cases in Möbler och heminredning $i$ svenska bygder Erixon published photographs by Nils Keyland. These pictures belong to the very few illustrations in his book that show people alongside with the depicted furniture.

In Svensk allmogekost Nils Keyland makes a remark of some theoretical interest when he notes that with his photo- 


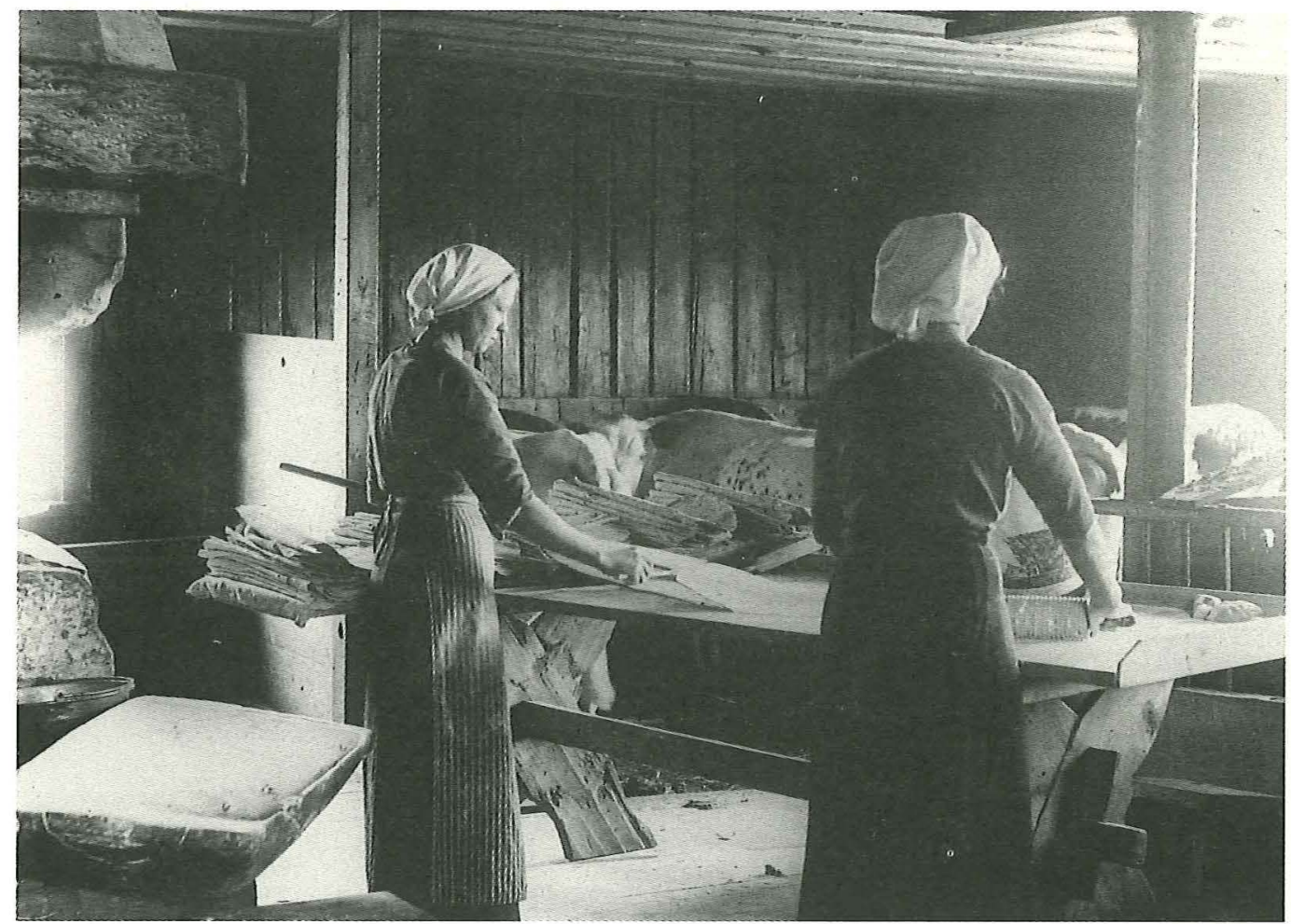

Photo no. 9. Women baking bread in a cow house, Alvros parish, 1915.

graphs he wanted to "depict situations» (aterge situationer). I believe the word «situations» is a true keyword, as it points to another content in Keyland's pictures, namely that he photographs people as if they were the subjects of his pictures. An illustration to this argument could be Keyland's photograph of a warp in use (photo no. 8). The presence of the child is important, because going round on the warp was something children enjoyed. The picture of the warp was taken in 1919.

Another photograph of some theoretical interest was taken by Nils Keyland in Älvros parish in northern Sweden in 1915 (photo no. 9). It shows two women baking a traditional kind of flat, unleavened bread, tunnbröd, in a cow house, where stoves traditionally were built due to the cold climate. What I appreciate in these two pictures is that Keyland let the persons act.

This is also the case with the four pictures showing «bundling», or nattfrieri (photos nos. 10-13). In northern Sweden bundling was the normal form for premarital contact between village boys and girls spending the night together in the girl's home. They were supposed to keep their clothes on and as a rule sexual intercourse was not allowed. Bundling practices were 
JAN GARNERT

178

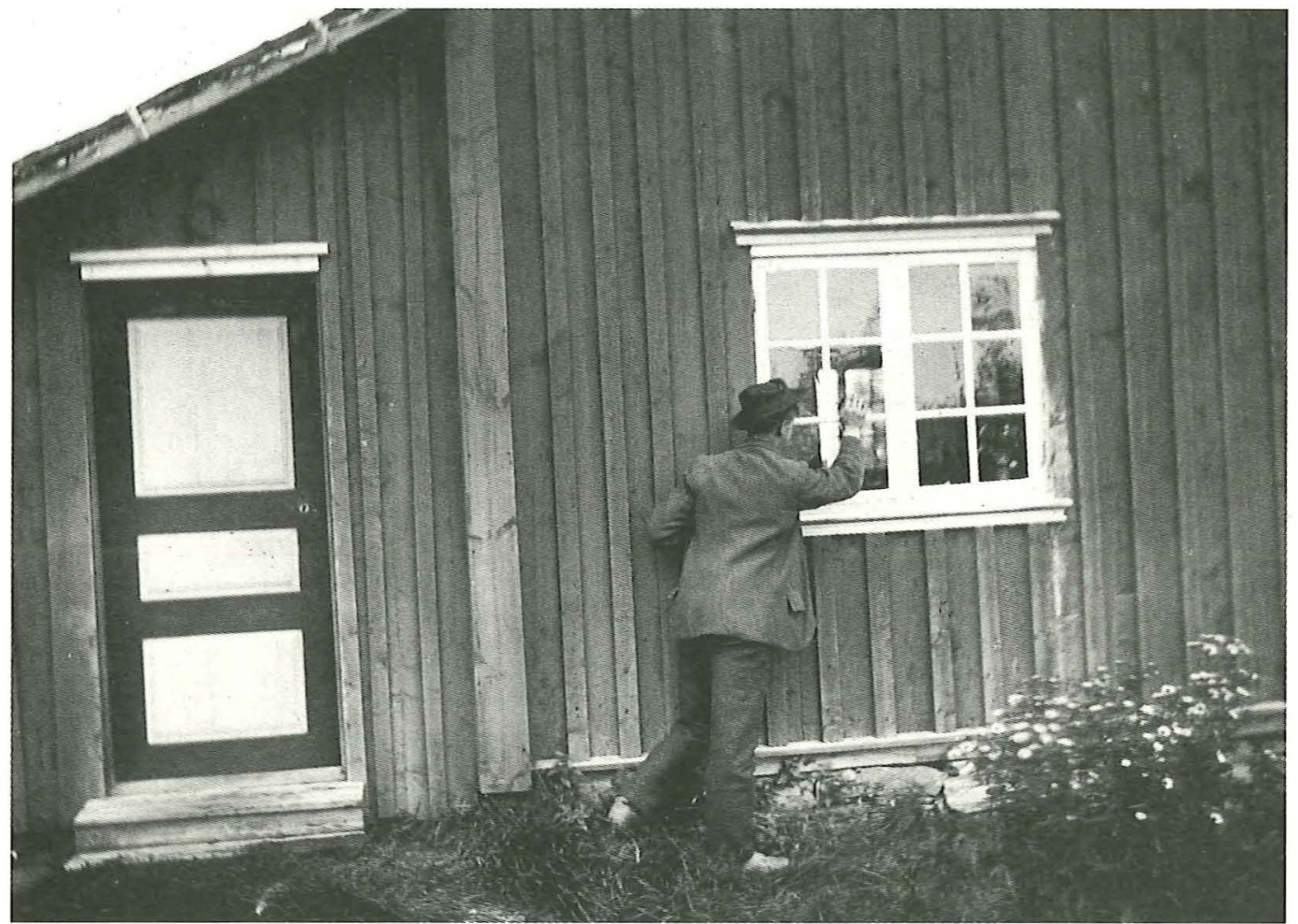

Photo no. 10. Bundling, Mangskog, 1912. The series continued on the opposite page (photos nos. 11-13).

closely connected with the independent position of unmarried girls in these northern parts, where the girls had their own sleeping quarters and spent long periods away from home, tending the cattle in outlying pastures. The strong social control of the village community made sure that no man should try to evade marriage if his bundling partner became pregnant. The photographs were taken in 1912 .

What inspired Nils Keyland to his extensive use of the camera? Was he perhaps inspired by the poignant documentary photographs of Jacob Riis, which appeared in US newspapers and in books like Riis' How the Other Half Lives, when Nils
Keyland was a temporary immigrant in the United States? Or did he explore the benefits of the camera from August Christian Hultgren, photographer at the Nordiska Museet between 1906 and 1912? Keyland and Hultgren had the American experience in common, and Hultgren's years at the Nordiska Museet coincide with Keyland's growing interest in photography, many of Keyland's best pictures having been taken in 1910-1912. Yet another driving force behind Nils Keyland's use of the camera may have been the use of photography by foreign ethnographers, whose work may have been well known to Keyland, who kept an 

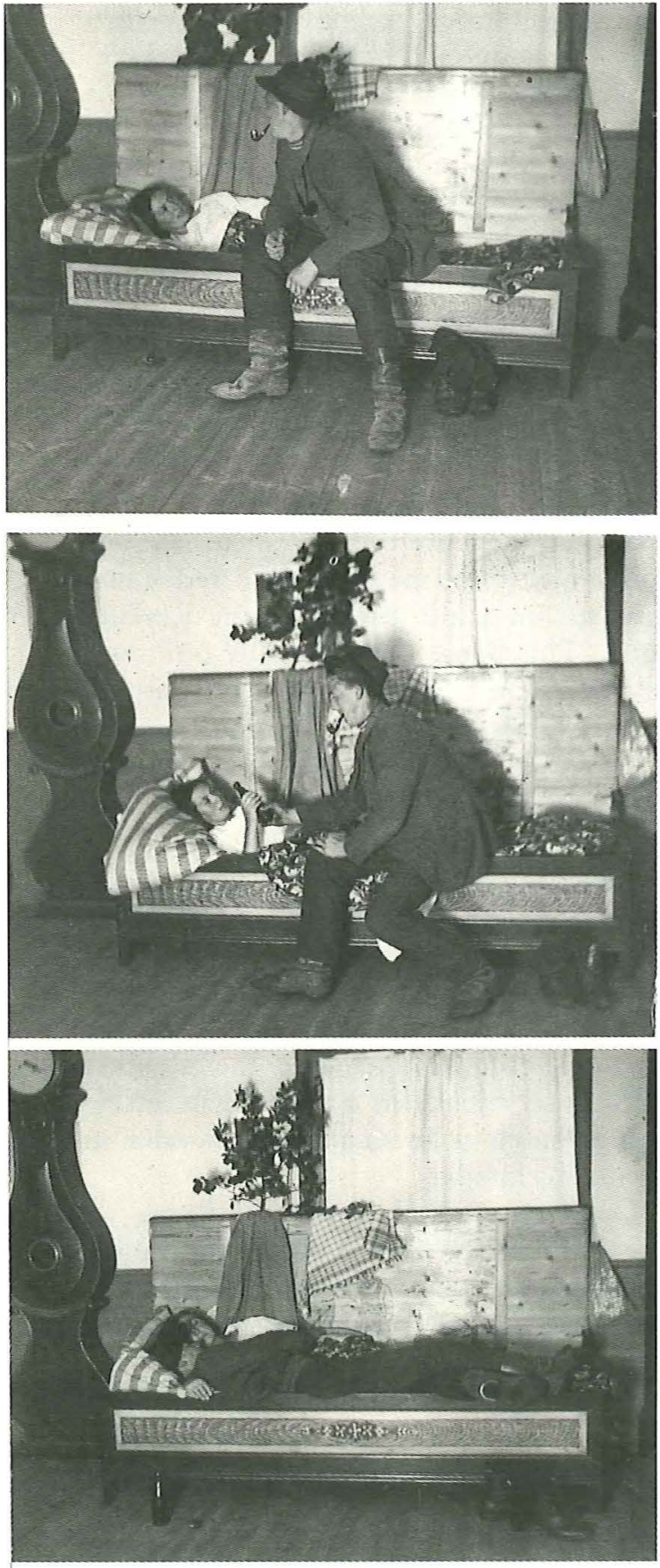

impressive private book collection in his apartment in Stockholm. All these suggested sources for inspiration remain assumptions.

\section{NEW PERSPECTIVES}

Writing the history of the cultural historical documentation at the Nordiska Museet, Nils Keyland's successors describe him as a researcher with roots deep down among the poor settlers of Finnish origin who broke new land in the woods of Central Sweden in the 17 th century. The importance of these roots was stressed when Keyland got his assignment at the Nordiska Museet, and when he passed away, his background was once again emphasized. A long article on Nils Keyland was published by C. V. Bromander in Fataburen, the yearbook of the Nordiska Museet and Skansen, in 1924. About Nils Keyland's background Bromander wrote: "The parental home was humble, and the family was forced, as generations before them, to struggle and labour hard, but gaining only a scanty living in the bare wilderness». (Bromander 1924, p. 184.)

This kind of characterization of Keyland's background was to be repeated in the coming decades. When a book with Keyland's posthumous articles and photographs was published in 1954, Gösta Berg, then a curator at the Nordiska Museet, quoted some of them and wrote that «his parents' home was poor and according to custom the little boy's likely fate was to be taught in the trades of his ancestors». (Berg 1954, p. 9.) Keyland is thus said to have come from a poor family of Finnish origin, yet he managed to beco- 
180 me a prominent researcher, working devotedly to preserve the folkways of his own ancestors.

Until early 1990, I also believed that this was the case. I believed that all I have so far told here about Nils Keyland was the actual story of his life and work. I had no reason to doubt it, since my sources for the biographical data on Nils Keyland were the writings by prominent folklorists and ethnologists in Sweden and some other sources, all safely independent of each other.

But in March 1990 I was giving a lecture on Nils Keyland in a location not far from where he came from. I then described him as a devoted folklorist of humble origins. In the audience there were people who protested, claiming that the Keyland family had not been poor at all. A day later I paid a visit to the still existing farmhouse of the Keyland family, now long since a summer house for a Stockholm family. I could at once determine that I was standing in front of a well built, rather impressive, two storey farmhouse covered with a typical well-to-do farmer's slate roof. The building was built like a typical farmhouse, but not like a simple Finnish farmhouse. A look in the taxation books from the early 20th century confirmed that Nils Keyland came from a rather wealthy family. Why, then, was the myth of the poor Finn Nils Keyland created?

One reason not to be neglected is that from the viewpoint of the curators at the Nordiska Museet, Keyland could perhaps be considered poor. After all, most professional folklorists and ethnologists clearly had an upper class background. Secondly, Keyland, a bachelor all his life and something of a bohemian who dressed rather carelessly, himself emphasized and deliberately romanticized his Finnish background. What's more interesting, though, is that the Nordiska Museet has turned this "poverty myth" into part of the museum's own history. Thus the Keyland legacy has been turned into "museum folklore».

It is obvious that not only Nils Keyland but his photographs, too, could be considered in more than one aspect. This was actually something I also became aware of while I was visiting the Keyland farm. I had brought some of his pictures with me and I enjoyed seeing the places where many of them were once taken. But my guide also took me to a little red house situated on a hill just above the Keyland farm. This house was originally built as a summer house in the early 20th century, and here friends of Nils Keyland's used to spend their summers. For a few years a doctor and his wife rented the house, later an artist stayed there for a few summers.

The summer was also the time of the year when Nils Keyland regularly returned home from Stockholm. According to the official story he was longing for his beloved home province. But could the case be that he enjoyed spending the summer with good friends in a vernacular setting just as much as he attached great value to seeing his family?

Upon entering the little red house on the hill I at once recognized the milieu from pictures taken by Nils Keyland. I was surprised. Had this house in fact worked as a kind of studio for folklore photography? Or should we rather consider it as fakelore, pictures taken of Stockholmers acting peasants?

Actually it has been long known that some of the persons who are portrayed in 
Photo no. 14. Child with walk-chair, Mangskog, 1920.

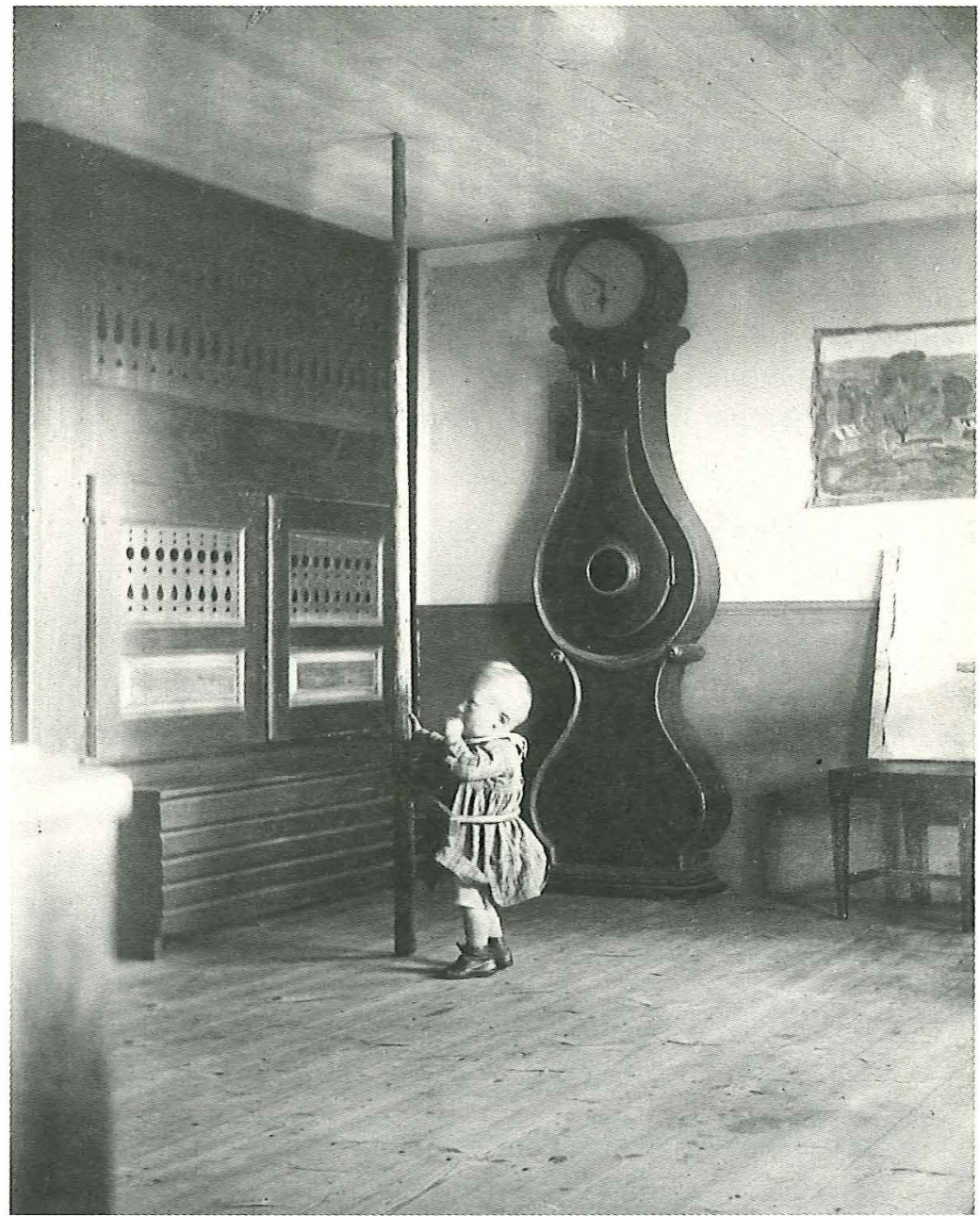

Nils Keyland's photographs are not from the vicinity. This goes for example for the pictures of bundling (photos no. 10-13). The woman is Eva Dahlstedt, the above mentioned doctor's wife, and she is even a countess. What has not been known before is that a considerable number of the pictures were taken in the little red house.

How should we, for example, evaluate photograph no. 14? It was published in
Erixon's Möbler och heminredning i svenska bygder, where the caption reads: "Cottage with walk-chair, Mangskog parish». But the photograph was taken in the little red house, which is definitely not a typical «cottage», and the pole was probably placed there only for the purpose of taking this photograph. There is reason to believe that the depicted child is not from Mangskog, but rather from Stockholm. 
JAN GARNERT

182 Many of Nils Keyland's photographs do, though, show natives of Värmland, acting in their own surroundings and carrying out familiar, everyday tasks. These photographs can be divided into two groups. One of them consists of photographs showing persons "acting themselves", the other group is made up of photographs depicting local people who demonstrate what Keyland knew were once folk customs. An example from the first group is the harvesting scene in photograph no. 15 .

An example from the latter group of photographs is the sauna bath from 1910 (photo no. 16). Keyland published the picture in his book on Christmas traditions, and his own caption reads: "Sauna bath. The housewife is pouring water on the stove. To the right a skin rug, hanging for cleaning.» (Keyland 1919, p. 90.) The woman who is about to pour water is Inga Persson, Nils Keyland's sister. One of the

On the opposite page: Photos nos. 16-17 Pictures from a sauna, Mangskog, 1910.

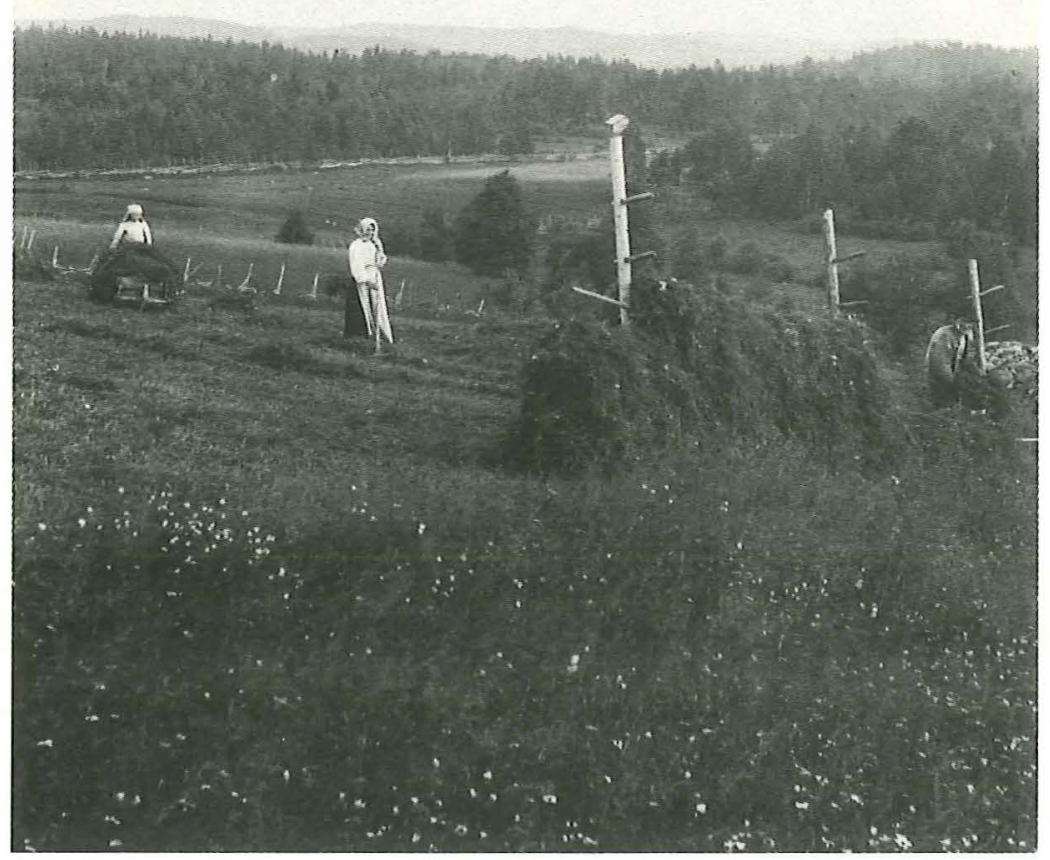



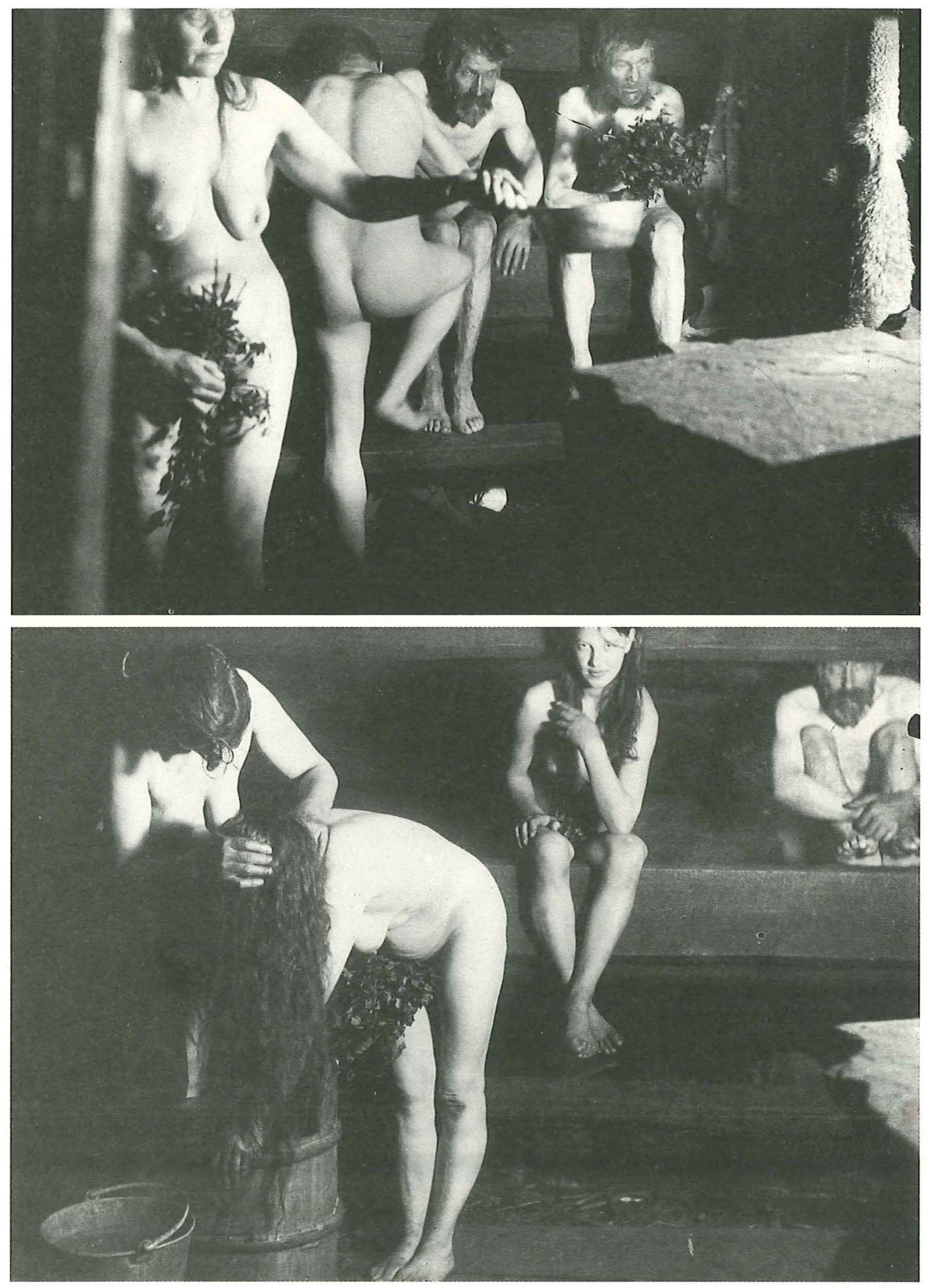

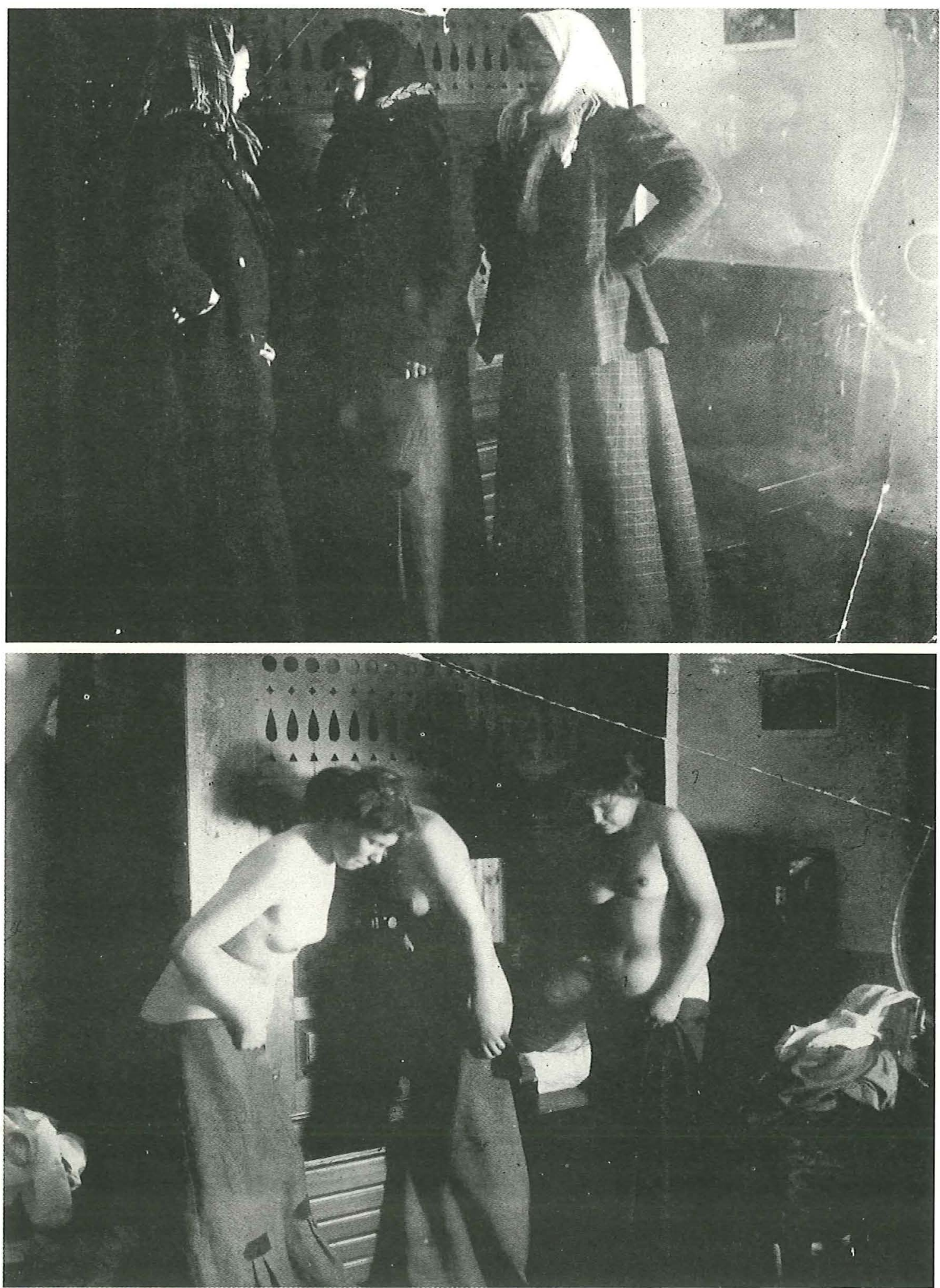

Photos nos. 18-19. Women photographed in "the little red house», Mangskog, date unknown. 
three men behind her is Inga's husband Magnus, one of the others is Inga's and Nils' brother August. When Nils Keyland took the photograph, sauna bathing was not customary in Mangskog, if practised at all.

Another photograph from the sauna shooting shows three women: Inga Persson, Stina Keyland, and Ester Gylén, a maid from Gunnarskog parish who was working for the Keylands. According to Keyland, his "pictures from a sauna ... were taken just before Christmas in 1910». (Keyland 1919, p. 89.) When Keyland published them, he did not comment on the circumstances under which the photographs were taken. Therefore, I believe, he gave the impression that they are authentic. It can be added that his book as a whole was meant to reproduce source material on Christmas traditions.

My re-evaluation of Nils Keyland as a photographer is supported by a collection of hitherto unknown photographs by him that I have come upon. Among them are two pictures of three women, first in traditional dresses, then photographed undressing - or vice versa (photos no. 18 and 19). If these had been women from the neighbourhood, they would probably have been more careful about their name and reputation, and would not have allowed Nils Keyland to photograph them nude. The photographs were taken in the little red house.

\section{RETHINKING AND RECONSTRUCTING}

How, then, are we to understand Nils Keyland's photographic ventures? My conclusion is that his photographs can be classified into the following four kinds:
1. Documents depicting, for example, houses and other buildings that were in use, and people "acting themselves», so to speak. These pictures, such as the one showing two women baking tunnbröd (photo no. 9), were documentation of contemporary everyday life and work.

2. Reconstructions in which persons who were familiar with a certain game or a type of work performed in front of the camera. What they carried out was already history, like the sauna bathing in pictures no. 16 and 17.

3. Reconstructions with the purpose of showing a certain technique of some kind, no matter who showed it and without paying attention to the context, as in photograph no. 20 showing young men performing various tricks.

4. Reconstructions in which Keyland's friends from Stockholm acted in situations reminiscent of the arrangements in exhibitions in the Nordiska Museet or at Skansen. This was carefully done to give the viewer an experience of a cultural historical insight. The photographs of bundling make an excellent example of this (photos no. 10-13).

It seems to me as if Nils Keyland, when photographing, did not have an ethical barrier or a theoretical division between documentation and reconstruction. This, I think, is the crucial point in his photography. It is a confusing and disturbing point and calls for a discussion of representation. What do these pictures actually depict? What do they represent? What kind of story is the photographer telling?

It is easy, and perhaps even cheap, to criticize Keyland for his doubly unrealistic photographs, in which the depicted situa- 
186 tion is a stage and the people depicted are actors in what to some of them must have been like participating in an ethnographic play. But the pictures also raise the question of whether they ought to be regarded as documentary photographs at all. If we treated his pictures as stage settings, kept as photographic illustrations, then we should perhaps also discuss them as if they were a kind of scenes in a theatre play, rather than documentary photographs.

Take, for example, photograph no. 21: «Movers' wagonloads with various tools» (Flyttlass med diverse redskap). What does this photograph show? Is this a document showing people about to move with all their stuff on the wagons, or is it an arranged situation? Or, has Keyland had his friends and relatives load the wagons and then act as if they are about to leave their old homestead? Or, maybe this picture actually shows two wagons full of artifacts that Keyland has collected for the Nordiska Museet and is now about to send to Stockholm? If so, perhaps he just seized the opportunity, took a photograph and called it "Movers' wagonloads with various tools».

I can't tell what this photograph actually shows, but you can note Nils Keyland's

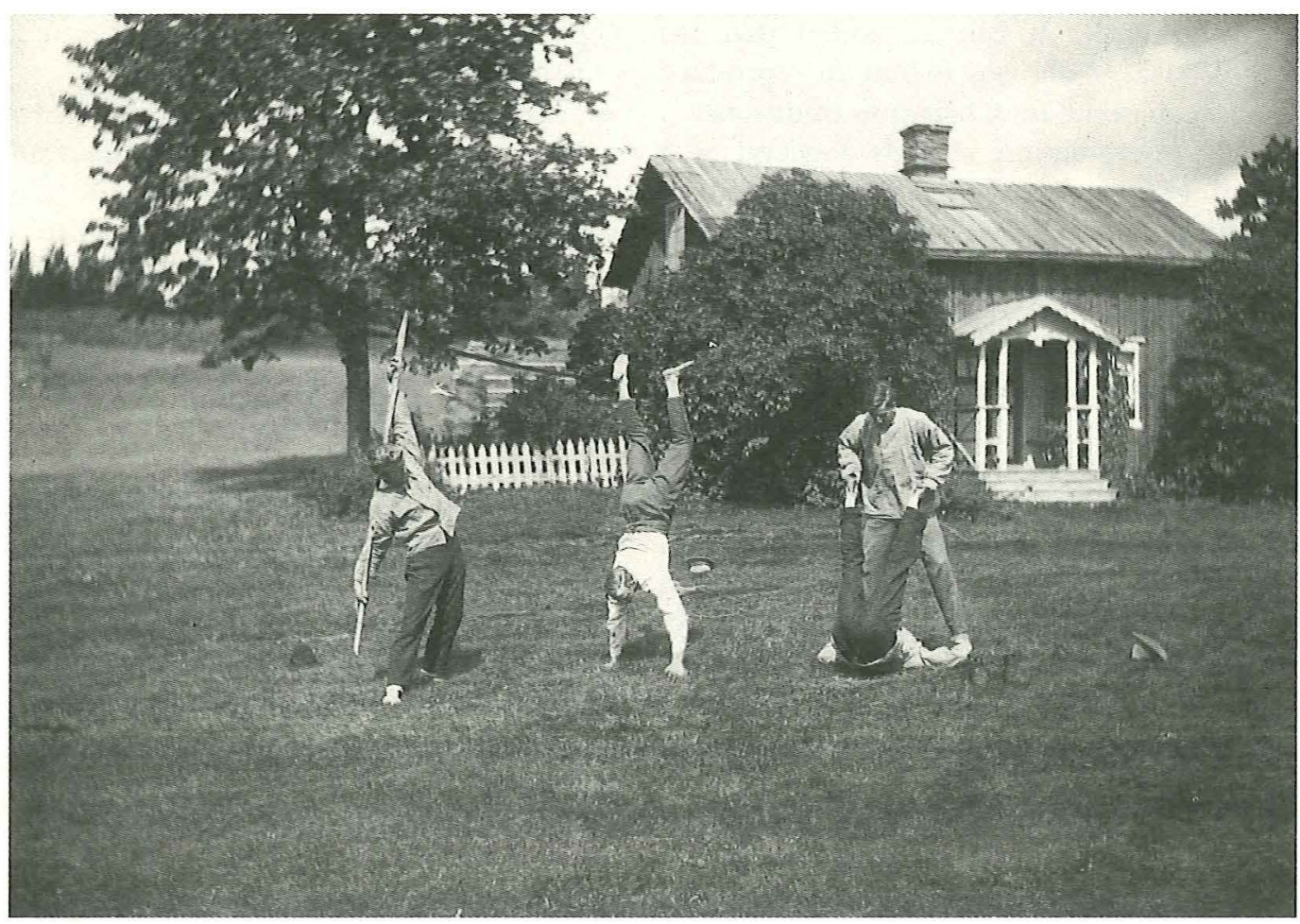

Photo no. 20. Young men performing games and tricks for Nils Keyland. The picture was taken in 1922 in fiont of the smaller of the two dwelling-houses at the Keyland farm in Mangskog. 


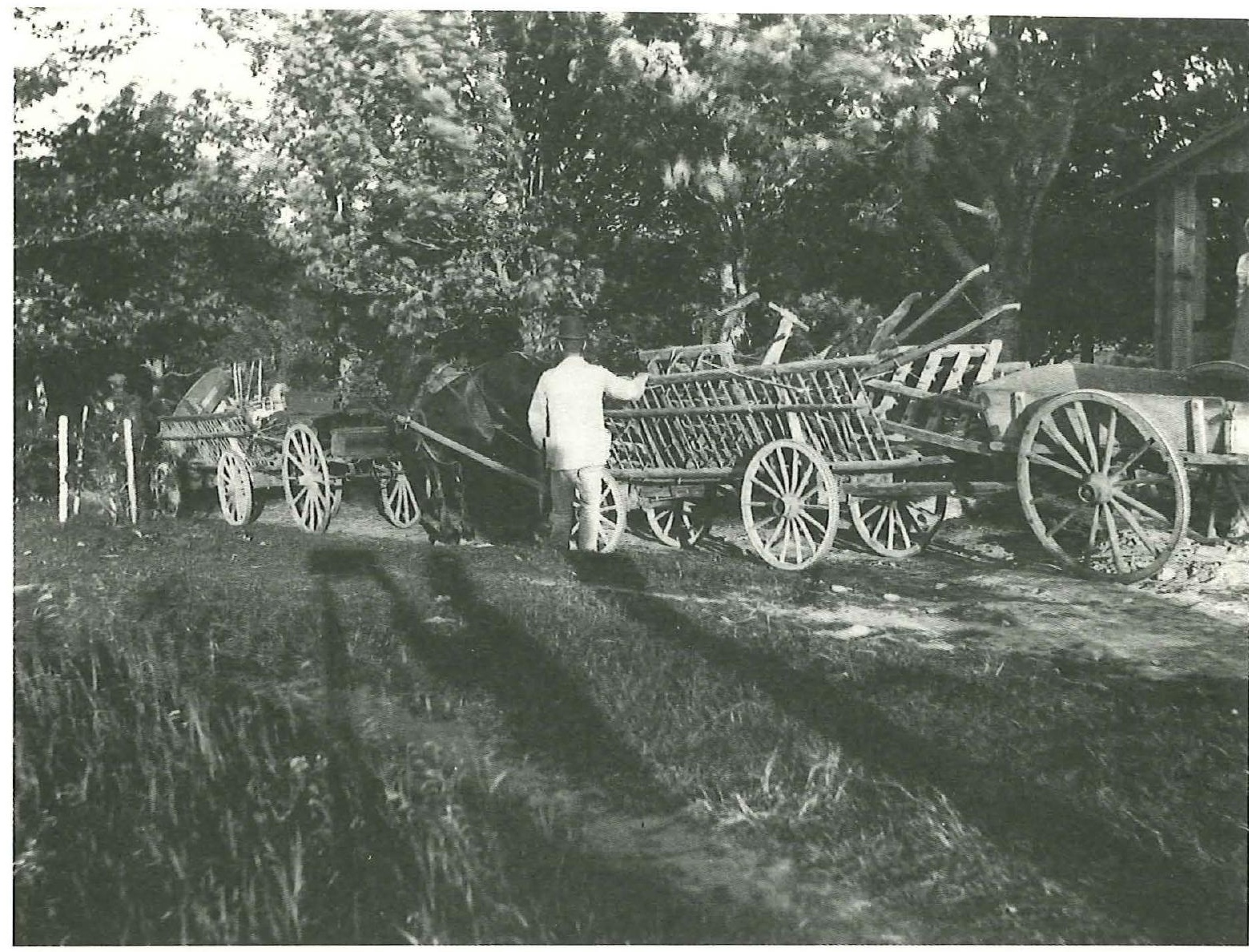

Photo no. 21. "Movers' wagonloads with various tools", Mangskog, 1911.

shadow cast along the grass. You can also recognize the shadow from his arm and hand, pressing the shutter release the very moment this photograph was taken, a summer evening in 1911. What was Nils Keyland up to? Was he about to make a document or not? Or is this another photograph for his folk theatre album? ${ }^{4}$

In a way it is not very surprising that Nils Keyland mixed ethnographic "fiction» with reality. After all, that was from 1906 onwards a task for him as amanuensis at Skansen, where Artur Hazelius had ever since the 1890's organized different kinds of "live» activities and performances. Here spinning wheels would hum, hand-looms would thud and the visitor's nose would be titillated by the smell of bread, fresh from the oven. A living museum presenting folklife in a lively way.

Those who performed at Skansen often originated from that part of Sweden in which the played part was thought to have taken place. In other cases those engaged as, for example, staff at a marketplace were

ladies from the Stockholm nobility, who dressed in traditional costumes and without no other reward than the pleasure of it ... served the visitors". (Biörnstad \& Liman 1972, p. 98).

This, I believe, might be the case with the woman depicted in photograph no. 22, taken by Keyland at Skansen. The woman, or, perhaps more adequate; the lady, is showing how to kindle fire.

Nils Keyland had himself a background as one of the performers of folk customs in these carefully directed public display events. Both before and after 1906, Keyland performed at Skansen as a story teller, speaking his native dialect, and cooking and serving traditional Värmland 


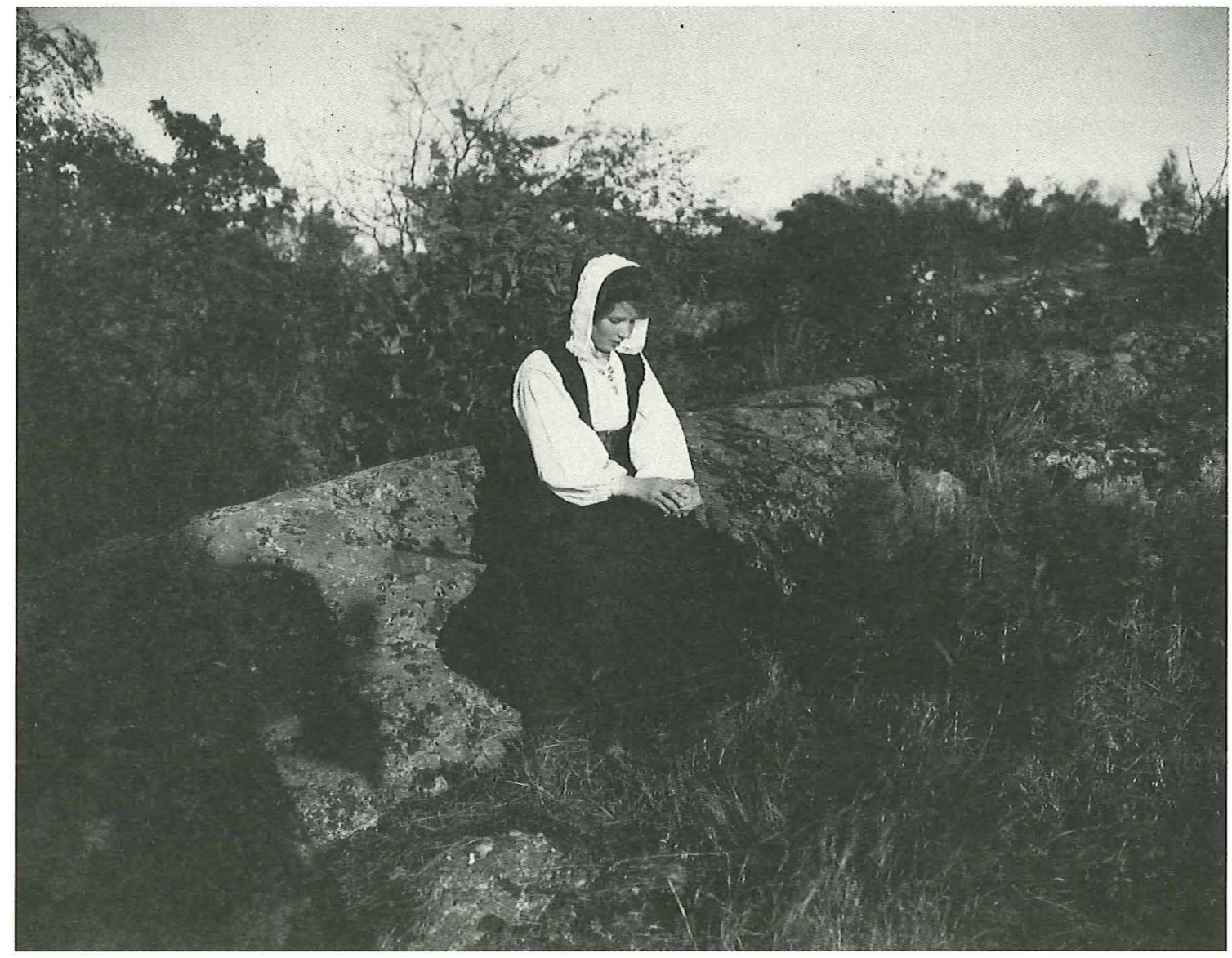

Photo no. 22. Woman showing how to kindle fire at Skansen, Stockholm, 1910.

dishes. Photography, I believe, was later to be utilized by him as just another means for the creation of cultural historical imageries.

This argument makes pictures like the ones of bundling understandable. One more point to remember, I think, is that these pictures were taken only a decade or two after the years of national romanticism in Sweden, when the upper classes amused themselves by dressing in traditional costumes and as Saamis. Even Skansen fits into the age of nationalistic romanticism, founded as it was in 1891 and representing a picturesque peasant Sweden. Skansen was for decades to come mainly visited by the upper classes of Stockholm. What Keyland could offer those of his friends who came to Värmland was some- thing quite exotic - to act as peasants, among peasants, in a village hundreds of miles from Stockholm, and for a scientific purpose.

It was in this village that Nils Keyland died on the 7th of July 1924. By coincidence, the last photograph of him was taken on that very day, while he was resting, sitting on a stone (photo no. 23). It is tempting to interpret this photograph symbolically, as it was taken right outside the little red house on the hill, from where one can look down to the Keyland farm, look down on it from the Stockholmers' point of view.

By way of conclusion, I would like to stress that Nils Keyland's works are an important contribution to visual folklore and anthropology, as he took pictures of 
working life, and socially meaningful situations, that no other professional folklorist and curator had paid interest to until then. But his photographic ventures also prove to be of significant theoretical interest as a case of how cultural historians have tended to nostalgize the history of their own profession. As I see it, the Keyland case is a warning to us, urging us to be careful with how we evaluate and interpret the history of our own profession.

The Keyland photographs also call for a close examination of the photographerresearcher as well as his or her works. What do his or her photographs represent? Nils Keyland's photographs also show that what we regard as source material in our archives - be it photographs or texts - are little more than cultural and historical artifacts: artifacts that are constructed by their own time, reconstructed by each succeeding era, and altered by editing, placement, and audience. (see Goldberg 1991, p. 17; Becker 1992.)

The questions can be put in a more general sense: What kind of dialogues and reflections does folkloristic and ethnological research make possible? What meanings do folklorists and ethnologists construct? An examination of the researcher as well as his or her works, can, I believe, give us a better understanding of the context, the validity as well as the limitations, of our discipline. This understanding is ethically and epistemologically important. At the same time it is obvious, I think, that understanding our own trade means nothing but a discerning and contipuous discussion of the character of follkloristic and ethnological research. In this process of considering and evaluating, the ques-

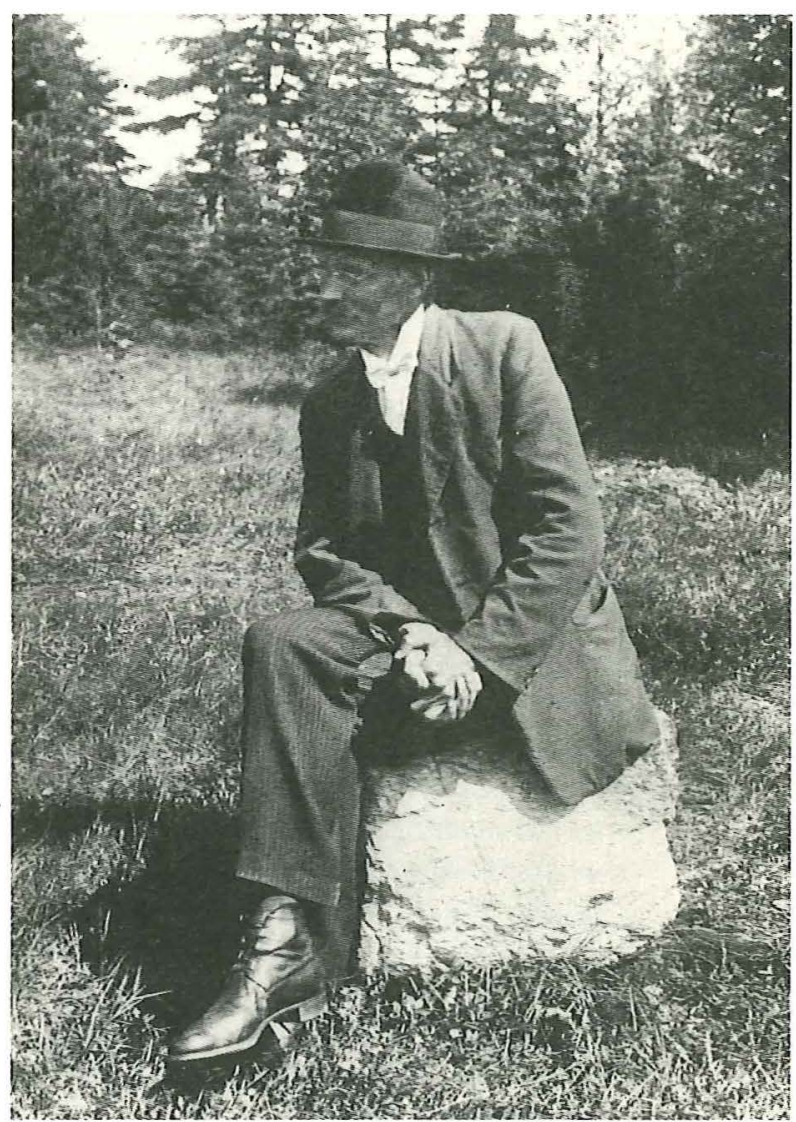

Photo no. 23. Nils Keyland photographed by Ludvig Mattsson on July 7, 1924.

tion of representation needs to be given an important position.

\section{NOTES}

1. The article was first published in Nordic

Frontiers. Recent Issues in the Study of Modern

Tradtional Culture in the Nordic Countries. Eds.

Pertti J. Anttonen and Reimund Kvideland. NIF

Publications No. 27. Turku: Nordic Institute of Folklore, 1993. It presents a work in progress, supported by a grant from the Erna and Victor 
190 Hasselblad Foundation, Gothenburg, Sweden. My sources are mainly from the archive of the Nordiska Museet, Stockholm, among them Nils Keyland's manuscripts, letters, some notebooks, and, of course, his photographs, which are reproduced courtesy of the Nordiska Museet. Nils Keyland's bibliography is included in Keyland 1954, pp. 79-81.

2. Karin Becker discusses the ideology of visual representation and, more specifically, photography's place in the Nordiska Museet between 1900 and 1940 (Becker 1992).

3. An enlarged edition of Erixon's book was published in 1938 under the title Folklig möbelkultur isvenska bygder.

4. Perhaps it is more justified to regard Nils Keyland's photographs in the literal sense that the word photography actually permits. The Greek photo means light, and graphein means to write. The words indicate that photographing means describing with a certain technique of using light. Thus, when Nils Keyland was not able to document, he staged what he wanted to show, using the camera as a useful tool for description. Perhaps this is what he was thinking of when he made the remark in Svensk allmogekost that he wanted to «depict situations".

\section{REFERENCES}

Becker, Karin 1992. Picturing Our Past. An Archive Constructs a National Culture. Journal of American Folklore 105: 3-18.

Berg, Gösta 1954. Nils Keyland som folklivsskildrare. Pp. 9-16 in: Nils Keyland, Folkliv $i$ Värmlands finnmarker. Efterlämnade uppsatser och bilder. (Nordiska museets handlingar 46). Stockholm: Nordiska museet.

Biörnstad, Arne \& Liman, Ingemar 1972 . Skansenprogrammen och tidsandan. Fataburen. Nordiska museets och Skansens årbok 1972: 97-112.
Bromander, C. V. 1924. Nils Keyland. Fataburen. Kulturhistorisk tidskrift 1924: 184-192.

Erixon, Sigurd 1925-1926. Möbler och heminredning $i$ svenska bygder. Stockholm: Nordiska museet.

Erixon, Sigurd (ed.) 1957. Atlas över svensk folkkultur. Atlas of Swedish Folk Culture. 1. Materiell och social kultur. Material and Social Culture. Uppsala: Academia Regia Gustavi Adolphi.

Goldberg, Vicki 1991. The Power of Photography. How Photographs Changed Our Lives. New York: Albertville Press.

Keyland, Nils 1919. Julbröd, julbockar och staffanssing. Dokument rörande den svenska allmogens julfirande. Stockholm: Svenska Teknologföreningen.

Keyland, Nils 1954. Folkliv $i$ Värmlands finnmarker. Efterlämnade uppsatser och bilder. (Nordiska museets handlingar 46). Stockholm: Nordiska museet.

Keyland, Nils (1919) 1989. Svensk allmogekost. Reprinted edition with a postscript by Jan Garnert. Stockholm: Carlssons Bokförlag.

Jan Garnert, PhD in ethnology, is presently engaged in a research project called "In the City After Dark", analysing the cultural bistory of night-time in Stockholm, fiom the 18th through the 20th century. Adr: Nordiska Museet, Box 27820,

S-11593 Stockholm

Fax +46-(0)8 7832840

e-mail: jgarnert@nordm.se 